\title{
The Effect of Woman Leadership Style and Organizational Culture on Locus of Control, Work Achievement, and Work Satisfaction of Employee
}

\author{
Andi Niniek Fariaty Lantara (Corresponding author) \\ Faculty of Economics, Moslim University of Indonesia - Makassar - Indonesia \\ Email: n_lantara@yahoo.com \\ Murdifing Haming, Abdul Rahman Mus, Roslina Alam \\ Faculty of Economics, Moslim University of Indonesia - Makassar - Indonesia
}

Received: October 18, 2012 Accepted: November 21, 2012 DOI: 10.5296/jpag.v2i4.2664

\begin{abstract}
Research begins from May to August of 2011 at The Governor Office of South Sulawesi Province. The objective of research is to understand and to analyze the direct and indirect effect of woman leadership style and organizational culture on locus of control, work achievement, and work satisfaction of employee. Research type is explanatory with survey method. The respondent is the work unit under the leadership of woman. Sampling technique is minimized sample method which results in 135 respondents. Data analysis method is Structure Equation Modeling (SEM). Result of analysis indicates that women leadership style is having positive and significant effect on locus of control, work achievement, and work satisfaction of employee.
\end{abstract}

Keywords: Women leadership, locus of control, work achievement, work satisfaction 


\section{Background}

Gender is becoming a widely spoken public discourse recently. This issue concerns with the partnership and the equity of social role between men and women. It is an issue that is constructed by religion, custom and culture which persists throughout human civilization. The boundary line of the role played by the men and women is blurred in the daily life. There are some roles underlining the custom and culture rather than religion, but others are concentrating on religion than custom and culture. A debate of legal status of women is always related to natural fate. Indeed, this natural fate entails the disposition of instinct, compassion, thinking model, and other undisputable provision except for the frame of thought (Tholchah, 2003).

In the end of 1998, Indonesia has begun to accept a discourse of woman leadership. Such idea triggers a polemic and debate between pro and contra of woman leader in a nation. In the patrilineal community, including Indonesia, men are given a noble position than women in all life aspects although the history notes that some women leaders are successful in leading a nation. It is an undisputable emancipative phenomenon, and even, women have sit on some important ranks in the community (Awuy, 1999).

Indonesia is a democratic country which respects to human rights, and therefore, never acknowledges the gender discrimination. Viewed from positive law (based on National Constitution), none of acts are prohibiting a woman from becoming a public leader. Therefore, any recommendations to reject the presence of woman leader will challenge the international idealism to support the woman dignity to engage within social and political lives on similar chance.

The politic situation in Indonesia has once given a fresh air to the woman perspective in the policy making. The development of this perspective is not optimal actually but the Political Party Act No.31 of 2002 has required $30 \%$ woman representatives. It is indirectly giving moral and psychological burdens for the organization participant of the election because the woman potentials are not anymore negligible.

Concerning with gender and leadership issues, Robbins (1998) provides two findings. First, equalizing men and women means disregarding the difference between both. Second, the difference between men and women in leadership is that women have more democratic leadership style. Women have a willingness to support the participation, to share power and information, and to improve "the utilization" received by the follower. They lead with participation or empowerment, and their leadership seems based on charisma, skill, contact, and interpersonal skill in persuading others. In contrast, men tend to use control-and-command leadership style. Men always care about the formal authority as their base in exercising the influence (Sudarmo, 2005).

Other factor affecting the employee's work achievement is personality factor, as shown by locus of control. According to Astuti (2007), locus of control is an attitude of someone to signify the cause of an event. It means that locus of control will be used as a consideration to determine the demand of information from a manager to predict environmental uncertainty in 
the managerial issue. Therefore, locus of control perceived by manager can be used as a mediator to strengthen or to moderate the relationship between woman leadership with work achievement and work satisfaction of employee. It contrasts with the finding of Reffiani (2009) that locus of control is simultaneously and partially not having a significant effect on work achievement through coefficient of determination of 0.07 or only $7 \%$. It is then certain that a research on the effect of woman leadership style and organizational culture on locus of control, work achievement, and work satisfaction of employee is conducted.

\section{Method of Research}

\subsection{Type and Design of Research}

Research uses an approach of level of explanatory. According to Sirigarimbun and Effendi (2002), the explanatory research is a research to explain an indication caused by an object of research by examining and identifying the relationship between variables through hypothesis testing. It is similar to Nazir (2007), which states that an explanatory research is to look for and to explain the causal relationship between variables through hypothesis testing.

\subsection{Research Instrument}

The data collection process is started by determining the variables which are to observe. These variables are given operational definition, and then, the indicators are measured. These indicators are elaborated into list/table containing the data (Sugiyono, 2002). The list/table of data is then becoming an instrument of research as a medium to collect primary data from respondents.

\subsection{Population and Sample of Research}

This research uses quantitative approach with survey method. This method means that the research will take sample from a population and use questionnaire as the main data collection device. The population is whole objects of research that are used as the source of data, sometimes with certain characteristic. The sample is a set of population that is becoming the real research object.

In obtaining the sample which represents the population, the sampling technique of Slovin Equation (Umar, 2004) is used as following:

$$
\mathbf{n}=\frac{\mathrm{N}}{1+\mathrm{Ne}^{2}}=\frac{782}{1+782(0.1)^{2}}=88,66=90 \text { people }
$$

where:

$\mathrm{n}=$ sample size

$\mathrm{N}=$ population size

$\mathrm{e}=$ the tolerance percentage of error due to sampling error 


\section{Macrothink}

\subsection{Type and Source of Data}

Type of data is qualitative and quantitative. Qualitative data are those obtained from interview, while quantitative data are in the numerical form obtained from questionnaire.

Source of data includes those obtained directly from the respondent, institutional documents, and written information with direct connection to the problem of research.

\subsection{Method and Tool of Analysis}

Method of analysis used in this research is Structural Equation Modeling (SEM) which is employed to understand the causal relationship between latent variables in the structural equation. The analysis tools involve reduced form and computer application program.

\section{Result of Research And Discussion}

\subsection{Result of Research}

The implication of result of analysis to the effect of woman leadership style and organizational culture on locus of control, work achievement and work satisfaction of employee is that the increase of locus of control is requiring the organization to increase woman leadership style. Result of analysis on the relationship between variables is shown in the following scheme (Fig.1):

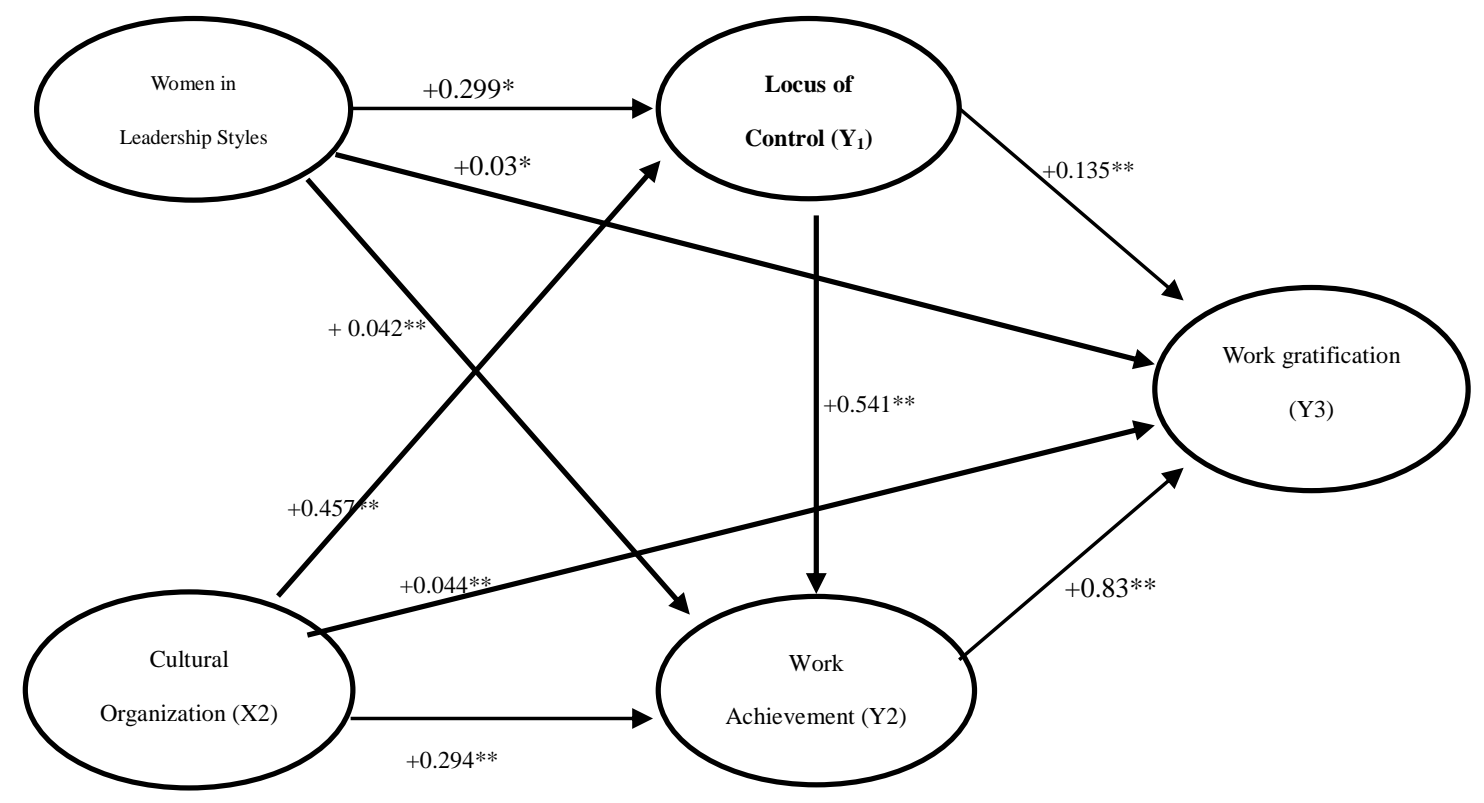

Description:

* Significant at $5 \%$ or less

** Significant at $1 \%$ or less

Figure 1. Result of Estimation in the Scheme 


\subsection{The Discussion of Result of Research}

3.2.1. The Analysis and Implication of The Effect of Woman Leadership Style and Organizational Culture on Locus of control

The coefficient of the effect of woman leadership style (X1) on locus of control (Y1) is 0.299 with t-value of 3.822 at significance rate of 0.000 . This coefficient indicates that the variable of woman leadership style (X1) has positive influence on locus of control (Y1). It also means that the increase of woman leadership style (X1) will be followed by the increased locus of control (Y1). Similarly, the decreased woman leadership style (X1) will also be followed by the decreased locus of control (Y1). Both situations are apparent under assumption that other factors affecting the increased or decreased locus of control (Y1) are considered as constant.

These results are consistent to Shinta (2006) who reports that a manager with internal locus of control is having greater willingness to give greater chance for the subordinate to express the opinion, if it is compared to a manager with external locus of control. Astuti (2007) adds that locus of control is an attitude of someone in defining the cause of an event. It means that locus of control shall be used as a consideration base to determine the demand of information from a manager to predict environmental uncertainty in the managerial issue. Therefore, locus of control perceived by manager can be used as a mediator to empower or to moderate the relationship between woman leadership with work achievement and work satisfaction of employee. Tannen (1995) asserts that a leader who underlines the relation and intimacy is represented by women. It is then possible that a leader who supports egalitarianism, empowering the constituent, and respecting the organizational structure is appointed among women. A leader who emphasizes on status and self-support is characterizing men, and therefore, it reflects a leader who will adopt hierarchical structure, specialization and command. The recent organization is always required to provide the quality service, to have a capability of high adaptation to the environmental change, to have organic structure, and to empower whole employees including superior and subordinate to produce the quality service.

The implication of this finding is that if an organization wants to improve locus of control of employee, the leader shall adopt woman leadership style characterized by transformational, democratic and participative.

The coefficient of the effect of organizational culture (X2) on locus of control (Y1) is 0.457 with t-value of 3.067 at significance rate of 0.002 . This coefficient rate shows that organizational culture (X2) has positive effect on locus of control (Y1). It means that the increased organizational culture (X2) will be followed by the increased locus of control (Y1). Conversely, the decreased organizational culture (X2) will be followed by the decreased locus of control (Y1), with assumption that assumption that other factors affecting the increased or decreased locus of control (Y1) are considered as constant.

These results are aligned with the theory proposed by Shinta (2006) who classifies the conditions into four groups of variable, such as: cultural, organizational, interpersonal and individual. In the cultural and organizational groups, internal locus of control is very important. Internal locus of control involves characteristics such as hard work, high initiative, 
exertion of problem solving, effective thinking, and perceiving that efforts are needed for success.

Locus of control can be defined as the perception of individuals on an event to understand whether the event that is experienced by them can be controlled or not (Falikhatun, 2003). Based on locus of control theory, individuals with unfavorable feeling against cultural environment in the organization or against the leadership style of superior over them as subordinate will always experience powerlessness and anxiety. In contrast, if individuals have convenience with cultural environment in the organization or with superior leadership style, they will show positive attitude and prefer to stay longer within the environment of organizational culture. By regarding to the values within someone else, these individuals attempt to select a specific role, assignment and even organization which conform to them. This conformity will produce work satisfaction, and then, it may stimulate someone to increase performance.

The implication of this finding is that if an organization wants to improve locus of control of employee, the leader shall create a good organizational culture.

3.2.2. The Analysis and Implication of The Effect of Woman Leadership Style, Organizational Culture and Locus of Control on Work Achievement

\subsubsection{The effect of woman leadership style on work achievement}

The coefficient of the effect of woman leadership style (X1) on work achievement (Y2) is 0.042 with $\mathrm{t}$-value of 2.276 at significance rate of 0.023 . This coefficient shows that the variable of woman leadership style (X1) has positive effect on work achievement (Y2). It means that the increased woman leadership style (X1) will be followed by the increased work achievement (Y2). The reverse is also obvious that the decreased woman leadership style (X1) is followed by the decreased work achievement (Y2) in the assumption that other factors affecting the increased or decreased work achievement (Y2) are constant.

These results of research are consistent to Schermerhorn (1999) who asserts that woman leadership style at certain level has leadership character toward transformational, which is leading by inspiring people to give more hard works to achieve the high performance. It is really differed from men who are more transactional, thus with leadership style toward directive (giving instruction) or assertive (aggressive and dogmatic), and exercising the authority to do "command-and-control" (Schermerhorn, 1999). The inspiring leadership is about how to inspire people to be more active in producing high performance, thus establishing the higher work achievement.

Hardini (2001), and Silverthorne \& Wang (2001) declare that leadership style may influence performance or productivity. The relationship between leadership style and employee performance can be indirect. Brownell and McInnes (1986) have examined the relationship between the participation in the budgeting and managerial performance. They estimate that the motivational participation can increase performance, but this hypothesis is not supported by the result. 
The implication of this finding is that if an organization wants to improve work achievement of employee, the organization shall improve its leadership style toward transformational.

\subsubsection{The effect of organizational culture on work achievement}

The coefficient of the effect of organizational culture $\left(\mathrm{X}_{2}\right)$ on work achievement $\left(\mathrm{Y}_{2}\right)$ is 0.294 with t-value of 7.529 at significance rate of 0.000 . This coefficient indicates that the variable of organizational culture $\left(\mathrm{X}_{2}\right)$ is having positive effect on work achievement (Y2). It means that the increased organizational culture (X2) is always followed by the increased work achievement (Y2). Conversely, the decreased organizational culture (X2) is also followed by the decreased work achievement (Y2), in the assumption that other factors affecting the increased or decreased work achievement (Y2) are considered as constant.

It is aligned with Hoftstede et al (2003) who admit that organizational culture entails professionalism, which represents a measure of skill and competence owned by the employee in the organization. A position occupied by a professional employee or a work conducted by a professional employee shall produce an optimal result. In the organization respecting professionalism values, all employees will view their work as a form of responsibility. Therefore, organizational culture respecting higher professionalism is surely producing higher work achievement.

The implication of this finding is that if an organization wants to increase work achievement of employee, the organization shall create an organizational culture which motivates the employee.

\subsubsection{The effect of locus of control on work achievement of employee}

The coefficient of the effect of locus of control (Y1) on work achievement (Y2) is 0.541 with $\mathrm{t}$-value of 12.458 at significance rate of 0.000 . This coefficient shows that the variable of locus of control (Y1) has positive effect on work achievement (Y2). It means that the increased locus of control (Y1) is followed by the increased work achievement (Y2). The reverse is also obvious that the decreased locus of control (Y1) is followed by the decreased work achievement (Y2) with the assumption that other factors affecting the increased or decreased work achievement (Y2) are constant.

These results are consistent to Crider (2003) who asserts that internal locus of control involves characteristics such as hard work, high initiative, exertion of problem solving, effective thinking, and perceiving that efforts are needed for success.

The implication of this finding is that if an organization wants to increase work achievement of employee, the organization shall increase self-confidence, or locus of control, of employee.

3.2.3. The Analysis and Implication of The Effect of Woman Leadership Style, Organizational Culture, Locus of Control and Work Achievement on Work Satisfaction

\subsubsection{The effect of woman leadership style on work achievement}

The coefficient of the effect of woman leadership style (X1) on work satisfaction (Y3) is 
0.030 with t-value of 5.339 at significance rate of 0.000 . This coefficient indicates that woman leadership style (X1) has positive effect on work satisfaction (Y3). It means that the increased woman leadership style (X1) is followed by the increased work satisfaction (Y3). Conversely, the decreased woman leadership style (X1) will be followed by the decreased work satisfaction (Y3) by the assumption that other factors affecting the increased or decreased work satisfaction (Y3) are considered as constant.

These results are aligned with Deddi Sunarto (2007) who reports that woman leadership style in the company has very great effect with work satisfaction rate of $56 \%$. It describes that the employees who work at PT. Asuransi Sinar Mas Cabang Medan have been satisfied with leadership style of the leader. Besides, Fuller \& Morrison (1999) add that leadership style can increase work satisfaction.

The implication of this finding is that if an organization wants to increase work satisfaction of employee, the organization shall improve leadership style to produce work satisfaction and good performance from the employee, by ensuring that the leader is not ambivalent in assessing the performance of employee, the leader is giving great attention to the work achievement of employee, and the leader has been more participative in the performance of employee by giving direction to the employee and providing personal attention to promote employee with hard work.

\subsubsection{The effect of organizational culture on work satisfaction of employee}

The coefficient of the effect of organizational culture (X2) on work satisfaction (Y3) is 0.044 with t-value of 3.047 at significance rate of 0.000 . This coefficient shows that the variable of organizational culture (X2) has positive effect on work satisfaction (Y3). It means that the increased organizational culture (X2) is followed by the increased work satisfaction (Y3). The reverse is also obvious that the decreased organizational culture (X2) will be followed the decreased work satisfaction (Y3) with the assumption that other factors affecting the increased or decreased work satisfaction (Y3) are considered as constant.

These results are consistent to Hoftstede et al (2003) who assert that organizational culture may involve integration, which is a climate established in the organization where the employee has strong attachment with organization. The employees may proud because they are recognized as the employee of organization and may feel secured for their work because they are respected and met for their life demand. The favorable work environment is also facilitated by good cooperation between employees or between departments, and thus, work satisfaction of employee is not impossible.

According to Robbins, the organization with such values will always produce work satisfaction of employee. If there is no conformity between employee characteristics and organizational culture, the employee will be less motivated and have low work commitment, which resulting in lower work satisfaction. A reasonable consequence is higher turnover of employees because they choose to move to other organization (Robbins, 1996).

The implication of this finding is that if an organization wants to increase the work satisfaction of employee, the organization shall establish organizational culture which gives 
great motivation to the employee.

\subsubsection{The effect of locus of control on work satisfaction of employee}

The coefficient of the effect of locus of control (Y1) on work satisfaction (Y3) is 0.135 with t-value of 6.596 at significance rate of 0.000 . This coefficient indicates that the variable of locus of control (Y1) has positive effect on work satisfaction (Y3). It means that the increased locus of control (Y1) will always be followed by the increased work satisfaction (Y3). Conversely, the decreased quality of locus of control (Y1) is followed by the decreased work satisfaction (Y3) with the assumption that other factors affecting the increased or decreased work satisfaction (Y3) are considered as constant.

These results are aligned with Robbins (1996) who declares that locus of control is related with work satisfaction such that if the employees show work satisfaction, their performance is increased.

Work satisfaction reflects an emotional attitude of employees about the work, and indeed, it is an assessment of employee over the favorability, positivity or negativity of the work. Michita and Frederic (2003) add that work satisfaction is a result of various attitudes possessed by a worker. This attitude is expressed in relative with the work or specific factors such as supervision, wage, opportunity of promotion, work condition, experience of skill, health work assessment, social relation at work, fast resolution against complaints, and good treatment from leader to the worker.

The implication of this finding is that if an organization wants to increase work satisfaction of employee, the organization shall bring locus of control of employee toward better direction.

\subsubsection{The effect of work achievement on work satisfaction of employee}

The coefficient of the effect of work achievement (Y2) on work satisfaction (Y3) is 0.830 with t-value of 25.395 at significance rate of 0.000 . This coefficient shows that the variable of work achievement (Y2) influences positively work satisfaction (Y3). It means that the increased work achievement (Y2) is followed by the increased work satisfaction (Y3). The reverse is evident such that the decreased quality of work achievement (Y2) will be followed by the decreased work satisfaction (Y3) with the assumption that other factors affecting the increased or decreased work satisfaction (Y3) are considered as constant.

These results are consistent to Ostroff (1992) who examine the relationship between work satisfaction, attitudes and performance of employee, with the result showing that there is a positive relationship between work satisfaction and attitudes with work achievement of employee.

Work achievement is related to the implementation of assignment based on the given responsibility, and thus, not related to the result (outcome) in economic term. Performance is measured from the work achievement of officer in determining work target, the attainment of work target, the work process, and the character of the officer (Minner, 2001).

The implication of this finding is that if an organization wants to increase the work 
satisfaction of employee, the organization shall increase work achievement of employee.

\section{Conclusion And Suggestion}

\subsection{Conclusion}

Based on the results of research, it is concluded that:

1. There is an effect from woman leadership style and organizational culture directly on locus of control, work achievement of employee, and work satisfaction of employee, as well as indirectly on work achievement through locus of control.

2. There is an effect from locus of control directly on work achievement of employee and work satisfaction of employee, and indirectly on work satisfaction through work achievement.

3. There is an effect of work achievement on work satisfaction of employee.

4. There is an effect of woman leadership style on work satisfaction through locus of control and work achievement.

5. There is an effect of organizational culture on work satisfaction through locus of control and work achievement.

\subsection{Suggestion}

1. The sustainability of the increased work satisfaction of employee is requiring the improvement of leadership style toward transformational, or called as woman leadership style, which is not ambivalent in assessing the performance of employee, giving great attention to the work achievement of employee, and more participative in the performance of employee.

2. The further research should add other variables such as work environment, organizational commitment, and others to enrich the research inventory about human resource management.

\section{References}

Astuti, E.D. 2007. Effect of Environmental Uncertainty Characteristics of Accounting Information Systems Management with moderation Locus of Control In Manufacturing Company in Yogyakarta and Central Java, thesis, Islamic University of Indonesia in Yogyakarta.

Awuy, Tommy F. 1999. "Mystification Nature Woman" in Tommy F Awuy (Editor) Discourse and Deconstruction Cultural Tragedy. Yogyakarta: Discourse Insight Publika.

Crider, Andrew B, (2003). Psychology. Scott, Foresman \& Company

Deddi Sunarto (2007) Analysis of women's leadership on job satisfaction of employees at PT Sinar Mas Medan Insurance. Thesis. Graduate Program University of North Sumatra.

Falikhatun. 2003. "The Influence of Organizational Culture, Locus Of Control and 
Application of Information System Apparatus Units of Public Service". Emprika. Vol. 16. 2 December. 263-281.

Hardini, Sri, 2001, "Relationships Influence Leadership Styles on Employee Job Performance KPKN Yogyakarta", thesis of Faculty of Economics, Gajah Mada University..

Hofstede, G., Bram Neuijen, Denise Daval Ohay and Geert Sanders, 2003. "Measuring Organizational Cultures : A Qualitative and Quantitative Study Across Twenty Cases". Administrative Science Quarterly, Vol. 35, p: 286- 316.

Miner, John B, 1992, Organizational Behavior Performance and Productivity, First Edition, New York: Random House, Inc.,

Nazir. (2003). Metode Research methods. (Third Edition). Jakarta: PT. Ghalia Indonesia.

Ostroff, 1992. "The realitionship Between Satifaction, Attitudes, and Performances An Organization Level Analysis. Journal of Applied Psycology. Vol 77 no 6.

Robbins, Stephen P., 1998, Organizational Behavior: Concepts, Controversies, Application, $8^{\text {th }}$ ed, Prentice-Hall International, Inc., New Jersey.

Schermerhorn, John R., Jr, 1999, Management, John Wiley \& Sons, Inc., New York.

Shinta Sari Purnama. 2006. Influence the capacity of individuals in Interaksikan with Locus of control towards budgetary slack. Thesis Graduate School of Gadjah Mada. Yokyakarta.

Silverthorne, Colin and Wang Ting-Hsin (2001), "Situational leadership style as a predictor of success and productivity among Taiwanes Business Organisations" Journal of Psycology, Vol. 135. No.4.

Singarimbun, Masri, dan Effendi Sofian. (1995). Survey research methods, London: LP3ES.

Sudarmo, 2006,"Perspective On Governance: Towards An Organizing Framework for Collaboratition and Collective Actions"; Public Spirit, Journal of Administrative Sciences, Vol 2 No.. 2, October, pp.113-120.

Sugiyono, 1999. Media Business Research. Jakarta: Publisher Alfabeta

Tannen, Deborah, 1991, You Just Don't Undersatnd: Women dan Men in Conversation, Bulletine Books, New York.

Tholchah Hasan , Muhammad 2003. Contenporer Islamic discourse. Listafariska Son. Jakarta

Umar, H. 1998. In the Human Resources Research Organization Dczya.. Jakarta: Gramedia. 